\title{
Erratum: Cost-effectiveness of strategies to improve the utilization and provision of maternal and newborn health care in low-income and lower-middle-income countries: a systematic review
}

Lindsay Mangham-Jefferies $^{1 *}$, Catherine Pitt ${ }^{1}$, Simon Cousens ${ }^{2}$, Anne Mills ${ }^{1}$ and Joanna Schellenberg ${ }^{3}$

\section{Erratum}

During the publication process of this article [1] a number of errors were unfortunately introduced into the references included in figure three, and were not noticed until after the final version had been published. The corrected version can be seen here (Figure 1).

\section{Author details}

'Department of Global Health and Development, London School of Hygiene and Tropical Medicine, London, UK. ${ }^{2}$ Department of Infectious Disease Epidemiology, London School of Hygiene and Tropical Medicine, London, UK. ${ }^{3}$ Department of Disease Control, London School of Hygiene and Tropical Medicine, London, UK

Received: 16 January 2015 Accepted: 16 January 2015

Published online: 21 March 2015

\section{Reference}

1. Mangham-Jefferies L, Pitt C, Cousens S, Mills A, Schellenberg J. Cost-

effectiveness of strategies to improve the utilization and provision of maternal and newborn health care in low-income and lower-middle income countries: a systematic review. BMC Pregnancy and Childbirth 2014;14:243.

* Correspondence: lindsay.mangham-jefferies@lshtm.ac.uk

'Department of Global Health and Development, London School of Hygiene and Tropical Medicine, London, UK

Submit your next manuscript to BioMed Central and take full advantage of:

- Convenient online submission

- Thorough peer review

- No space constraints or color figure charges

- Immediate publication on acceptance

- Inclusion in PubMed, CAS, Scopus and Google Scholar

- Research which is freely available for redistribution

Submit your manuscript at

www.biomedcentral.com/submit

\section{Ciomed Central}

(c) 2015 Mangham-Jefferies et al.; licensee BioMed Central. This is an Open Access article distributed under the terms of the Creative Commons Attribution License (http://creativecommons.org/licenses/by/4.0), which permits unrestricted use, distribution, and reproduction in any medium, provided the original work is properly credited. The Creative Commons Public Domain Dedication waiver (http://creativecommons.org/publicdomain/zero/1.0/) applies to the data made available in this article, unless otherwise stated. 


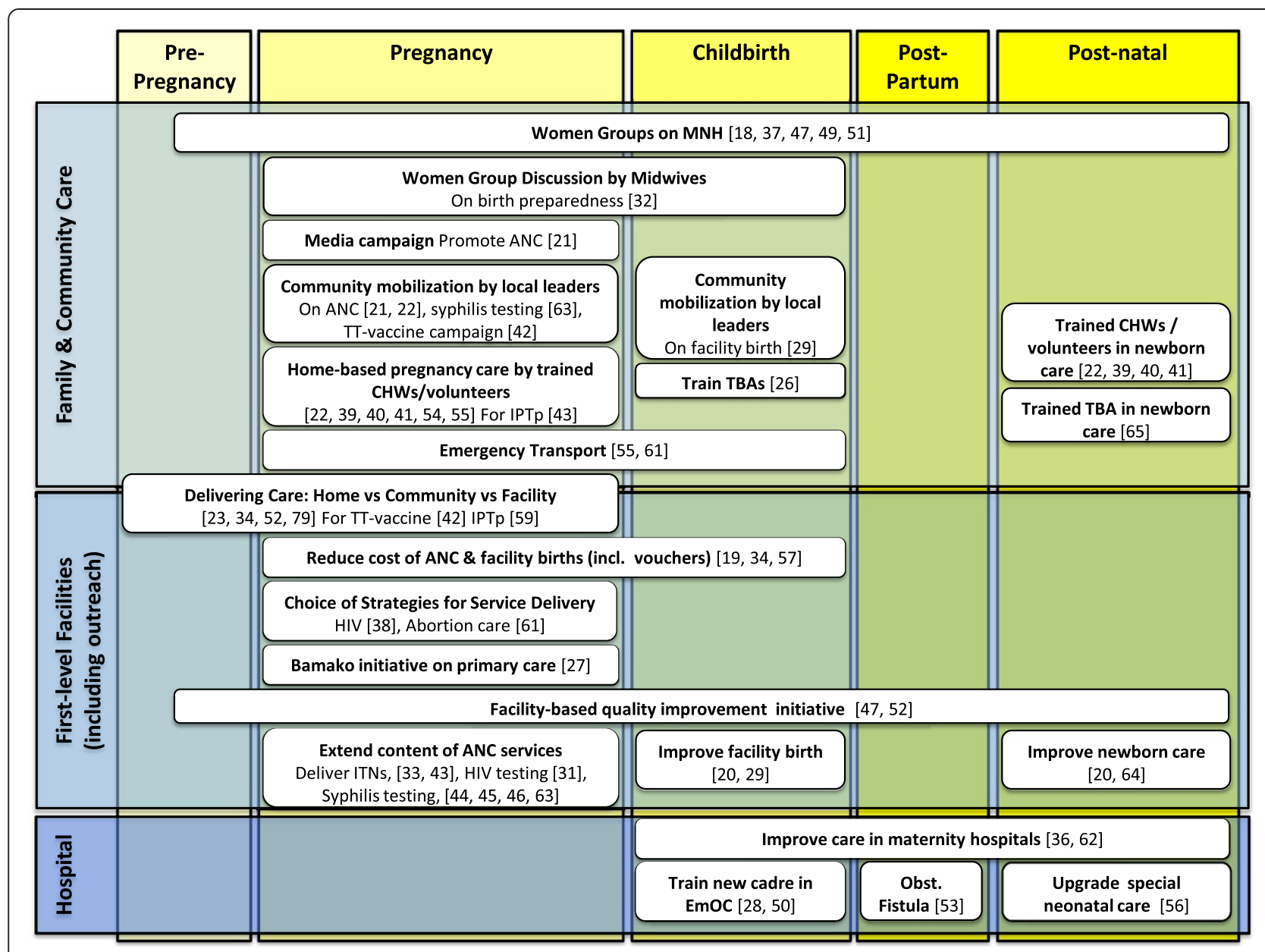

Figure 1 Innovations by place of care and lifecycle in the continuum of care. 